Maria Stopa-Boryczka, Maria Kopacz-Lembowicz, Jolanta Wawer

\title{
THE CLIMATE OF WARSAW IN THE RESEARCH CONDUCTED AT THE DEPARTMENT OF CLIMATOLOGY OF WARSAW UNIVERSITY
}

The problem of urban climate has been on the research agenda within the Department of Climatology of Warsaw University since 1952. Most of attention was paid to the study of the climate of Warsaw, a city of $533 \mathrm{sq} . \mathrm{km}$ of surface area and more than 1,600,000 inhabitants.

The numerous research reports devoted to this problem area were based both on the archival material from the weather stations of the Institute of Meteorology and Water Economy (located at Warsaw-Okęcie, Bielany, Astronomical Observatory, and the River Pump Station), or the own weather station of the University, and on the rich material from the studies carried out by the Department (Fig. 1) within many housing estates featuring a variety of structure and density characteristics, as well as various shares of greenery. These estates included Stawki, Służew nad Dolinka, Stegny, Chomiczówka (high-rise, loosely distributed structures with little greenery), Sady Żoliborskie, Szwoleżerów (low-rise, architecturally differentiated buildings, important share of greenery), and the Olimpijska estate (family housing). Studies were also conducted along the profiles crossing the town from North to South and from East to West, in the parks, in the streets characterised by varying exposure to the inflow of the air, as well as on the embankment of the Vistula river valley.

Multiannual characterisations of the meteorological elements made it possible to demonstrate the specific features of the urban areas. The impact of the town on the state of the atmosphere is measured with the differences between the town and its surroundings, provided in Table 1.

Thus, when seen against the surrounding areas, Warsaw distinguishes itself with the decreased influx of radiation, higher air temperature (especially the minimal one), longer period without ground frosts, lower relative humidity and bigger air humidity deficiency, bigger cloudiness and smaller number of sunny days, bigger precipitation, and lower velocities of winds (Stopa-Boryczka et al., 1984, Stopa-Boryczka, 1992).

A particular attention has been paid in the reports concerning the climate of Warsaw to the urban heat island. The heat island in Warsaw is not a persistent, stable phenomenon, and it displays periodical fluctuations, both in 
Table 1.

The biggest differences of the average values of the meteorological variables between the centre and the peripheries of Warsaw, calculated on the basis of the observations from the period 1961-1965 and from the year 1969

\begin{tabular}{|c|c|c|}
\hline No. & Name of the variable and the measurement unit & Difference \\
\hline 1. & Daily average of air temperature $\left({ }^{\circ} \mathrm{C}\right)$ & 1.1 \\
\hline 2. & Maximum temperature $\left({ }^{\circ} \mathrm{C}\right)$ & 0.5 \\
\hline 3. & Minimum temperature $\left({ }^{\circ} \mathrm{C}\right)$ & 2.0 \\
\hline 4. & Days with ground frost $\left(t_{\min }<0^{\circ} \mathrm{C}\right)$ & -10 \\
\hline 5. & Frosty day $\left(t_{\max }<0^{\circ} \mathrm{C}\right)$ & -5 \\
\hline 6. & Water vapour pressure $(\mathrm{hPa})$ & -0.5 \\
\hline 7. & Relative humidity (\%) & -5 \\
\hline 8. & Deficiency of air humidity (hPa) & 1.8 \\
\hline 9. & Cloudiness $(\%)$ & 4 \\
\hline 10. & Sunny days (in a year) & -4 \\
\hline 11. & Cloudy days (in a year) & 18 \\
\hline 12. & Foggy days (in a year) & -18 \\
\hline 13. & Precipitation (mm, in a year) & 75 \\
\hline 14. & Days with precipitation $>0.1 \mathrm{~mm}$ (in a year) & -8 \\
\hline 15. & Days with precipitation $\geq 1.0 \mathrm{~mm}$ (in a year) & 7 \\
\hline 16. & Days with precipitation $\geq 10.0 \mathrm{~mm}$ (in a year) & 2 \\
\hline 17. & Days with storms (in a year) & -7 \\
\hline 18. & Days with snow cover (in a year) & 4 \\
\hline 19. & Wind velocity (m/sec.) & -1.4 \\
\hline 20. & Days with strong wind ( $\geq 10 \mathrm{~m} / \mathrm{sec}$, in a year) & -8 \\
\hline 21. & Number of calms & 97 \\
\hline 22. & Total radiation sums (MJ/sq.m month), 1969 & 58.6 \\
\hline 23. & Pollution (dust deposition in tons per sq. $\mathrm{km}$ in a month), 1969 & 110 \\
\hline
\end{tabular}

the daily, and in the annual cycle. Within the 24-hour cycle the biggest difference of temperature between the town and the peripheries is observed in the evening and during the night. In the annual cycle, on the other hand, the biggest temperature differences are observed in the period between April and October, while the smallest — in November and in March (Fig. 2) (Kossowska, 1973; Kossowska-Cezak, 1977; Stopa-Boryczka et al., 1994, 1995).

The heat island is definitely most pronounced during summer (in July), attaining, on the average, in the central regions of the town the temperature difference $\Delta \mathrm{T}$ close to $2^{\circ} \mathrm{C}$, while in other areas of town, farther from the centre, the difference is by half smaller. The analysis of the annual course of the increments of air temperature in the town provides information on the rate of heating up and cooling down of the town with respect to the areas without urban structures. The areas featuring intensive urban-type land use are characterised by a slow rate of cooling and warming, especially in summer months.

The properties of the urban heat island (its intensity) depend upon the time of the day, the season of the year, and the weather conditions existing during the 24-hour cycle. 


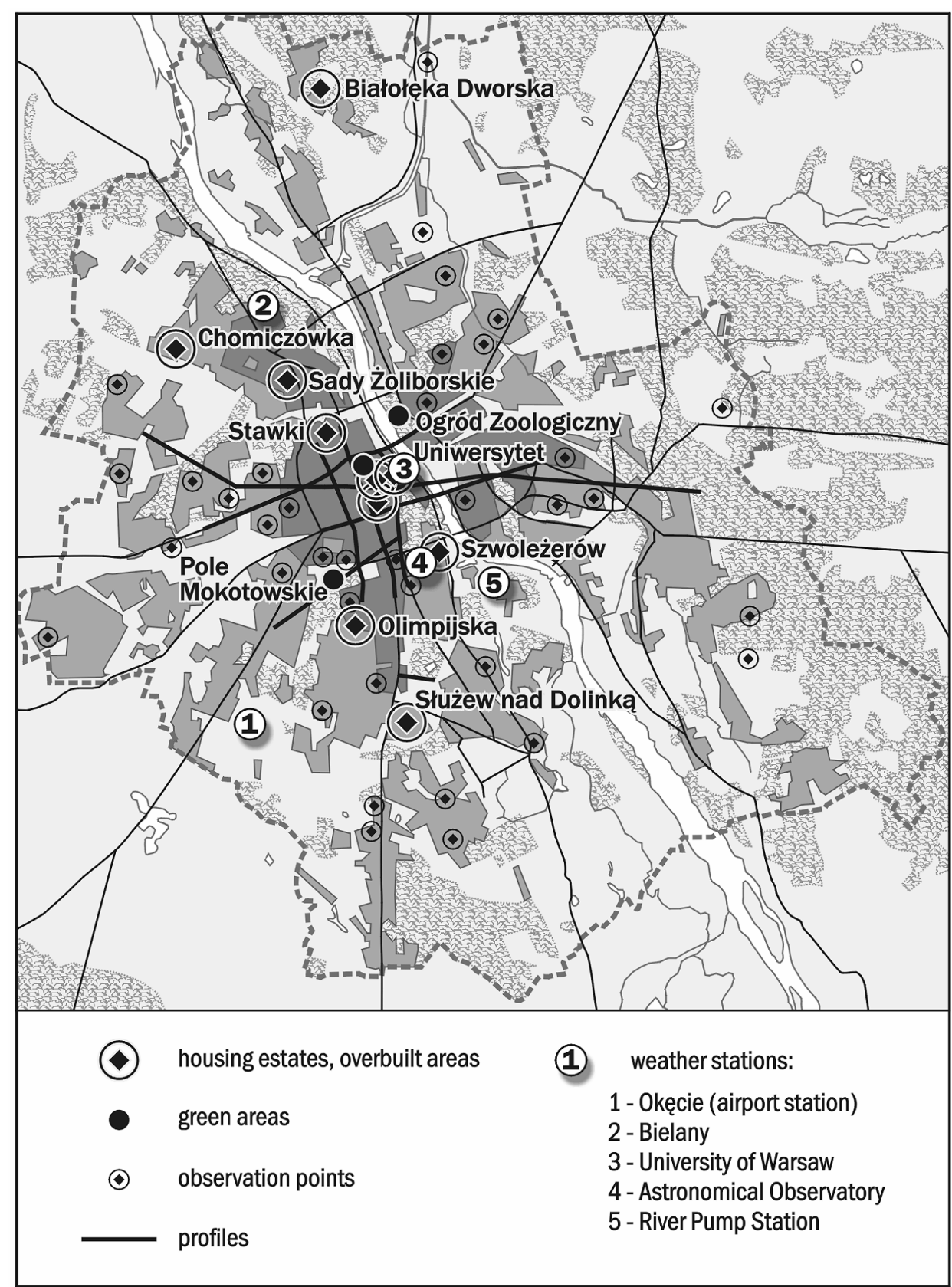

Fig. 1. Climatological field studies carried out in Warsaw by the Department of Climatology of the University of Warsaw. 


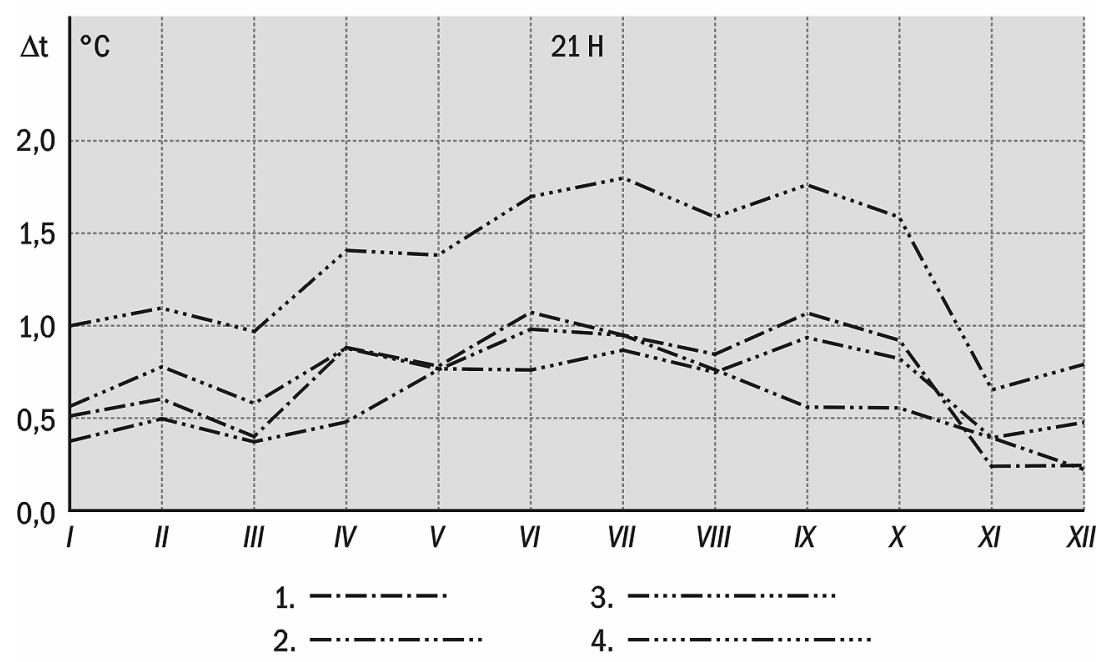

Fig. 2. Air temperature differences between the urban weather stations and the Okęcie weather station in the evenings (9:00 p.m.) in the years 1961-1965. 1 - Bielany, 2 - River Pump Station, 3 - Astronomical Observatory, 4 - University of Warsaw.

The analysis at the level of the 24-hour cycle demonstrates that the urban heat island appears in the cooler part of the year (especially between December and March) usually during the entire daily cycle. This is the effect of the thermal impact from the structures, along with the influence of the "artificial heat". During the summer season, on the other hand, the heat island intensifies in the evening and during the night, in view of radiation of the heat, previously accumulated by the artificial bedding and its slower radiation than outside of town. In the time around noon, however, it is often cooler in town than in the peripheries. The highest daily differentiation of the heat island is observed in summer and in the early autumn (Stopa-Boryczka, 1988, 1998; Wawer, 1998).

Thus, the intensity of the heat island is influenced both by a number of meteorological elements, and the factors of a different nature, the anthropogenic ones (magnitude of town, its compactness, location, etc.).

Among the meteorological elements it is the wind and the cloudiness that exert the strongest influence on the heat island. The increase of wind velocity decreases the possibility of accumulation of heat reserves in town, especially in the cooler part of the year. When wind velocity exceeds $7 \mathrm{~m} / \mathrm{sec}$, , the differences of air temperature between the town and its surrounding gradually disappear. It was assumed that limit value of wind velocity, at which the heat island disappears, is $9-10 \mathrm{~m} / \mathrm{sec}$. Low wind velocities, and in particular the calms, are, on the other hand, advantageous for the persistence of the heat island.

An increase of cloudiness decreases the intensity of the heat island. On the other hand, the cloudless sky, and the small degree of cloudiness - up 
to 2 (on the scale between 0 and 10), are conducive to persistence of the thermal differences between the town and its peripheries.

It is also very important to identify the daily changes in the air temperature differences $\Delta \mathrm{T}$ between the particular areas of town and the peripheries. This allows for determination of the time of appearance of the heat island (Table 3), of its maximum intensity, as well as its weakening or demise. One can, as well, precisely determine the rate of heating and cooling of the air in the downtown and peripheral areas (Table 2) (Wawer, 1996).

Table 2.

The rates of warming and cooling of the air in downtown Warsaw and in the peripheries in particular seasons of the year $\left({ }^{\circ} \mathrm{C} /\right.$ hour $)$

\begin{tabular}{|l|c|c|c|c|}
\hline \multirow{2}{*}{$\begin{array}{c}\text { Season } \\
\text { of the year }\end{array}$} & \multicolumn{2}{|c|}{ Rates of warming } & \multicolumn{2}{c|}{ Rates of cooling } \\
\cline { 2 - 5 } & downtown & periphery & downtown & periphery \\
\hline Winter & $0.2-0.1$ & $1.5-2.5$ & $0.1-0.7$ & $1-3$ \\
Spring & $0.3-2$ & $1-3$ & $0.1-0.7$ & $1-3$ \\
Summer & approx. 1 & $1-3$ & $<1$ & $1-5$ \\
Autumn & $1-2$ & $1-3$ & $1-2$ & $2-3$ \\
\hline
\end{tabular}

Table 3.

Characteristics of the urban heat island in Warsaw in particular seasons of the year

\begin{tabular}{|l|c|c|c|c|c|}
\hline $\begin{array}{c}\text { Season of } \\
\text { the year }\end{array}$ & $\begin{array}{c}\text { Time } \\
\text { of appearance } \\
\text { of the heat } \\
\text { island (hour) }\end{array}$ & $\begin{array}{c}\text { Time } \\
\text { of appearance } \\
\text { of the maximum } \\
\text { (hour) }\end{array}$ & $\begin{array}{c}\text { Time } \\
\text { of weakening } \\
\text { of the island } \\
\text { (hour) }\end{array}$ & $\begin{array}{c}\Delta \Delta_{\text {(in }}{ }^{\circ} \mathrm{C} \text { ) } \\
\text { during } \\
\text { the day }\end{array}$ & $\begin{array}{c}\text { Extreme } \\
\text { values } \\
\text { of }{ }_{\Delta} T\end{array}$ \\
\hline Winter & $16: 00-18: 00$ & $21: 00-24: 00$ & $6: 00-7: 00$ & $>0$ & $9-11$ \\
Spring & $17: 00-18: 00$ & around $24: 00$ & $7: 00-8: 00$ & $\leq 0$ & 9 \\
Summer & $18: 00-20: 00$ & $22: 00-24: 00$ & $6: 00-8: 00$ & $<0$ & 8 \\
Autumn & $16: 00-18: 00$ & $21: 00-01: 00$ & $6: 00-9: 00$ & $<0$ & 8 \\
\hline
\end{tabular}

Thus, it turns out that the urban heat island in Warsaw assumes the highest intensity (the biggest positive differences between the centre of town and the peripheries) during the days with anticyclonal (high pressure) circulation. The absolutely biggest observed difference of air temperature between the town and its surroundings occurred under the anticyclonal type of circulation with the centre over Poland (Wawer, 1992, 1998).

In the course of analysis of the differentiation of climatic conditions within town the characteristic features of the local climate were determined for the urban areas with compact and loose distribution of structures, for the green areas, as well as for the streets of various directions (Mierzwiński, 1988; Stopa-Boryczka et al., 1986). The analysis encompassed the process of heat exchange, the rate of warming and cooling, the deformation of the flow field within the overbuilt areas, as well as the differentiation of air humidity. The analysis of differentiation demonstrated that the fragments of the town with 
high density of structures, or the larger areas of the park greenery, as well as the closed quarters housing estates, feature a distinct tendency towards the appearance of the "conserving" heat effect. This is most clearly pronounced during the abrupt weather changes (rapid cooling or warming), and is associated with the decreased degree of ventilation of such areas. Now, the rates of warming and cooling of the overbuilt areas of the selected estates with respect to the surroundings, can be illustrated with the following example. The housing estates with high rise block structures, such as Służew nad Dolinka or Stawki, heat up with the intensity by $0.2^{\circ} \mathrm{C}$ lower than the surroundings. This means that when the surroundings heat up by $1^{\circ} \mathrm{C}$, the estate heats up by just $0.8^{\circ} \mathrm{C}$, and thus becomes cooler. The process of warming up of the air takes a different course in an estate with the family housing structures and a high share of green areas (Olimpijska). The influence of the different types of structures is even more strongly pronounced in the process of the evening cooling. The complex of the tall buildings of the housing estate Służew nad Dolinka cools down with the rate lower by $0.4-0.3^{\circ} \mathrm{C}$ than the surrounding areas, so that when the air temperature outside of the estate falls down by $1^{\circ} \mathrm{C}$, it only decreases by $0.6^{\circ} \mathrm{C}$ inside the estate, which thereby becomes increasingly relatively warm in the evening. In the family housing residential areas the cooling down takes a less intensive course: the decrease of temperature outside of the estate by $1^{\circ} \mathrm{C}$ is accompanied by the decrease inside it by $0.9^{\circ} \mathrm{C}$. The differentiation of the rates of cooling is illustrated in Fig. 3.

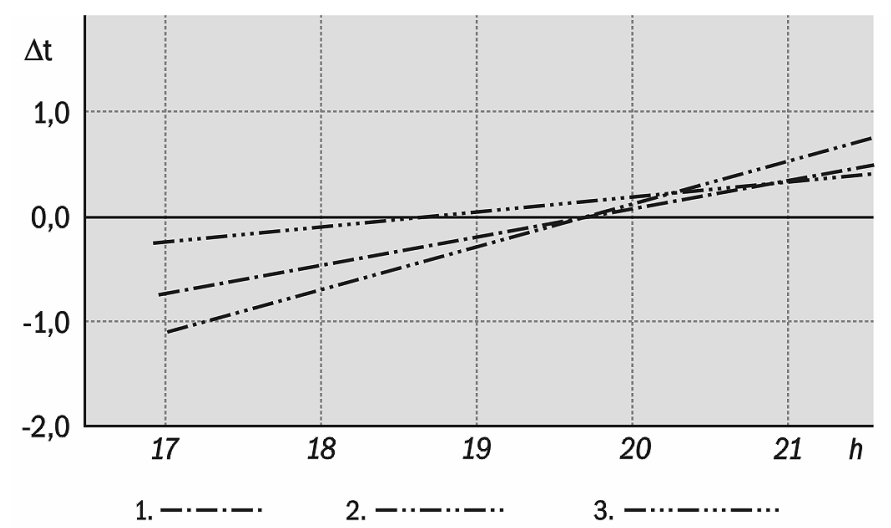

Fig. 3. The dependence of the difference between the average air temperature in the points inside the estates and an external reference point as a function of time. 1 - housing estate Stawki (tall buildings), 2 - housing estate Służew (tall buildings), 3 - housing estate Olimpijska (low buildings).

The study of the different housing estates in Warsaw suggests that the air in the estate warms up in the morning hours less intensively, and in the evening hours cools down with the intensity lower by $1 / 3$ than in the surrounding areas. Hence, the influence of the urban structures on the air 
temperature fields is at its maximum in the early morning and late evening hours.

The establishment of the rates of warming and cooling of the housing estates with various kinds of structures, and of the differentiation of the heat reserves between the entire town and its surroundings allows for the identification of a very important process taking place in the overbuilt areas the local circulation of the air, that is, the process, which to a large extent enhances the ventilation of the town (Stopa-Boryczka et al, 1994, 1995). The dynamisation of the air exchange, leading to the thinning of the urban aerosol and to the self-purification of the air, is an essential problem in every large town. It is estimated that approximately $70 \%$ of pollution come from transport. While the level of industrial pollution has been in the recent years stabilised, the degree of hazard resulting from the transport-generated pollution is on the rise.

Two ventilation systems function in towns: the external and the internal one. The external system is constituted by the wind, which, as it penetrates into the environment characterised by different physical features, is being modified. The internal system is constituted by the local circulation within the confines of the urban organism, conditioned thermally and dynamically. The systems mentioned, depending upon the atmospheric macro-circulation, may both contribute to the process of urban ventilation, or one of them starts to prevail, in some cases taking over entirely the role of the ventilating factor.

Warsaw, due to its location and the surface relief, is open to the free inflow of the air from all the directions. It is essential, though, to what extent the air that flows into the area of the town may play the role of the ventilating factor.

Fig. 4 presents the characteristic features of the air flowing over Warsaw from various directions. It was assumed that the winds having velocity lower than $5 \mathrm{~m}$ per second in the open space, after having slowed down by approximately $30 \%$ within the urban structures will not be considered sufficient for ventilation of the central areas of town. The most frequently flowing in air from the western sector (NW, W, SW), characterised at the weather station of Niepokalanów by the highest frequency $(48.2 \%)$ and the highest average velocity $(4.4 \mathrm{~m} / \mathrm{sec}$.), turns out to be "useful" for the ventilation of the city in only $14.4 \%$ of cases. The inflow of the air from other directions ensures the effective ventilation of Warsaw (winds of more than $5 \mathrm{~m} / \mathrm{sec}$. of velocity) to an even lower degree. Winds play appropriately their ventilating role only in the cooler part of the year (Stopa-Boryczka et al., 1994). In the summer the exchange of the air in the central areas of town is insufficient. Therefore, there is a need for ensuring a more intensive local air exchange.

The most effective forces, acting in the direction of dilution of the urban aerosol and the self-purification of the air during the day are the convection currents. The different degrees of the warming of the neighbouring active surfaces give rise to the vertical, convection movement, and consequently to the local flow of the air between the surfaces featuring significant thermal 


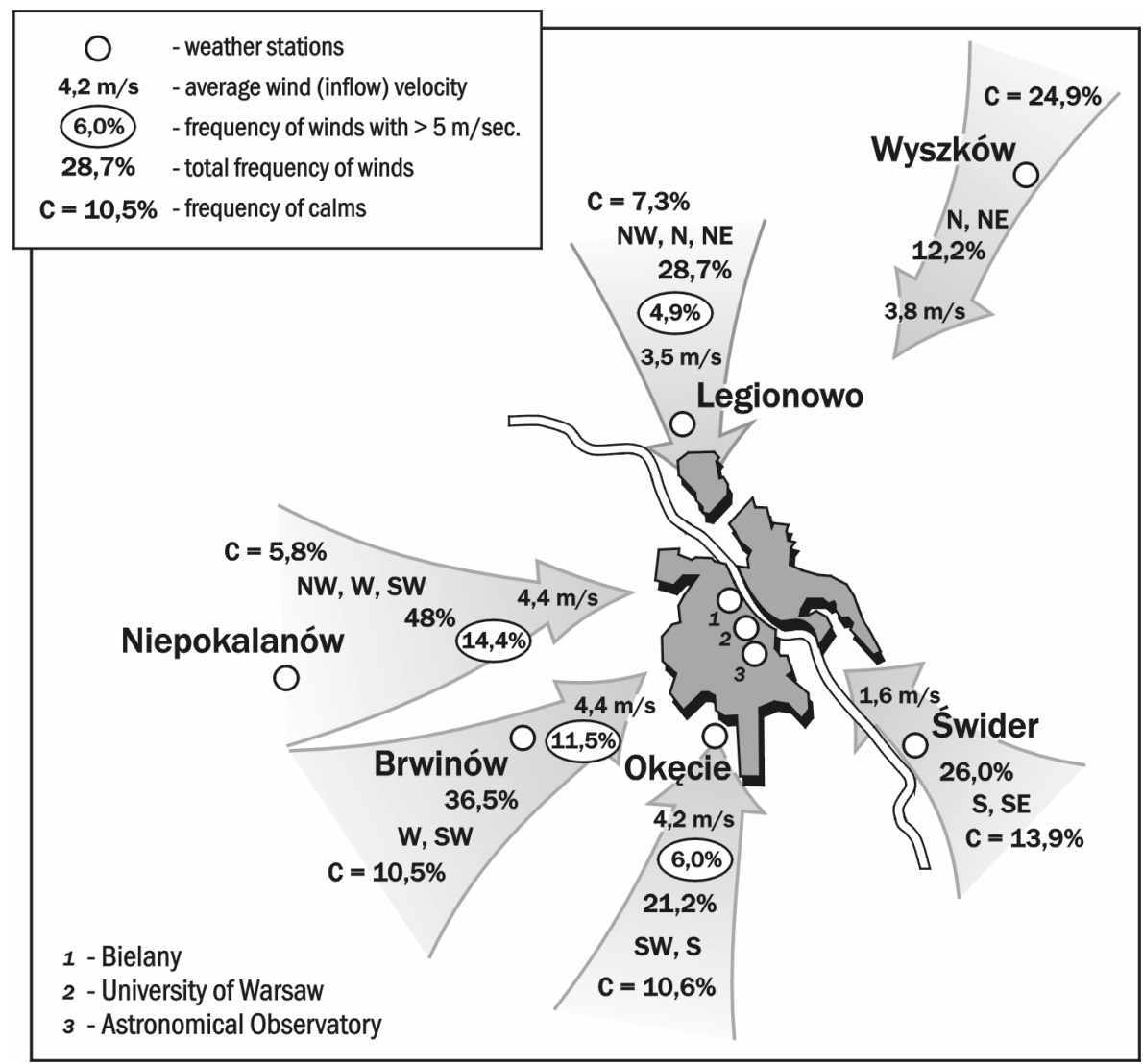

Fig. 4. The scheme of the wind inflow over Warsaw (1951-1960).

contrasts. A typical contrasting setting in the towns is constituted by an overbuilt area neighbouring upon a green area. The difference in the warming of these areas may attain, under definite weather conditions (intensive radiation, and calm or weak wind), a dozen or degrees centigrade. The thermal contrasts observed most often in Warsaw were of the order of a couple of degrees.

The rising current of warm air entails suction. The trajectory of the convection current will therefore constitute a kind of a "chimney" bringing pollution above the structures. The location and density of these "chimneys", as well as fields of the contrasted surfaces, can be regulated depending upon needs. It seems that it is most advisable to activate the vertical exchange of the air in the central parts of the town. Convection currents are the fundamental factor in the self-purification of the air during the day under windless weather, or with weak air movements. The moderate winds partly contribute to this process, while the stronger winds, exceeding $7 \mathrm{~m} / \mathrm{sec}$., take over the function entirely. 
During the night, under windless weather and clear sky, the only factor ensuring the air exchange in Warsaw is the so-called urban night breeze, which emerges due to the increasing thermal contrasts between the slowly cooling down overbuilt area and the quickly cooling urban periphery. The air currents develop then, flowing on the lower side towards the centre, and replacing the warm air, which rises above the downtown. A circulatory air movement develops of different reach, which brings the air that is not always quite fresh and pure, like when the polluting objects are located in the surroundings of the town. Because of this, it is advisable to have on the way of the air currents, directed towards the town's centre, the areas of greenery, playing the role of a filter.

Yet, in connection with the intensification of construction projects in many areas of the town in the recent years, the existence and the functioning of the wedges aerating the city was clearly disturbed.

The indicators of the correct ventilation of the overbuilt areas may be constituted by the purity of the air and the advantageous conditions of the thermal feeling of the inhabitants of the town, especially in the warm part of the year.

In the summer the inhabitants of Warsaw are often exposed to the conditions leading to overheating, caused by the joint action of high air temperature, intensive solar radiation in the non-shaded areas, weak movement of the air, and the additional effect - radiation of heat energy from the warm walls of buildings and the streets. The onerous character of these conditions consists in the incorrect heat exchange between the human organism and the atmospheric environment due to the too low cooling capacity of the air. This kind of disadvantageous weather situation appears in the centre of Warsaw on the average during $20 \%$ of the summer days, while outside of town they are two times less frequent.

A decrease in the share of these disadvantageous conditions could be to a significant degree secured by the appropriate design of the green areas within the housing estates and the parks (Kopacz-Lembowicz et al., 1984). It is recommended to design the tall greenery not in the form of larger compact areas, but rather as loose clusters. Thereby, the throughflow of the air will not be hampered, playing in such situations the essential cooling role, nor will the pockets of humid air develop, adding to the hardship related to the high temperature. Thus, for instance, the measurements of the cooling capacity of the air (catathermometric), carried out in July 1975 in one of the downtown parks (the Saxon Garden), showed that despite the slightly lower air temperature values in comparison with the neighbouring Victory Square, the hard to bear feeling of sultriness attained in the mid-day hours the frequency of $75 \%$, while in the Victory Square it would not exceed the frequency of $37 \%$. In these conditions the free outflow of heat, having been produced owing to the metabolic transformations, from the human organism, is hampered, and the state of stifling heat, according to the scale of perception of Petrovič and Kacvinsky, would set in. 
Thus, the larger areas of greenery should have places with an intense movement of the air, as well as places protected from the wind, so as to ensure for the inhabitants the possibility of taking leisure outside also during the cool, windy days, when the wind causes an excess cooling of the organism.

When selecting the specie composition of the vegetation in the parks the species ought to be accounted for, which produce the volatile bactericidal substances - the phytoncides.

Likewise, the greenery accompanying the transport axes, whose main task is to stop the solid state pollutants and to absorb the gaseous ones, as well as to lower the level of noise, is also very important. The elements of this greenery are the trees, the shrubs, and the ground level vegetation, which are resistant to the action of the street aerosol.

The studies conducted constitute the basis for the design of the spaces that are appropriately differentiated in thermal and dynamical terms, and thereby to the shaping of the desired micro-climate in the town.

\section{REFERENCES}

Kopacz-Lembowicz M., Kossowska-Cezak U., Martyn D., Olszewski K., 1984, Wpływ zieleni miejskiej na klimat lokalny [The influence of the urban greenery on the local climate], [in:] Polish, in: Wpływ zieleni na ksztattowanie środowiska miejskiego, Szczepanowska (ed.), PWN, Warszawa.

Kossowska U., 1973, Osobliwości klimatu wielkomiejskiego na przykładzie Warszawy [The singularities of the metropolitan climate on the example of Warsaw; in Polish], Prace $i$ Studia IGUW, 12, series Klimatologia, 7.

Kossowska U., 1977, Warunki termiczne Warszaw [Thermal conditions of Warsaw; in Polish], Prace $i$ Studia IGUW, 22, series Klimatologia, 9.

Mierzwiński B., 1988, L'influence des conditions atmosphériques sur l'île urbaine de la chaleur à Varsovie, Miscellanea Geographica, vol. 3.

Stopa-Boryczka M., Kopacz-Lembowicz M., Kossowska-Cezak U., Ryczywolska E., Wawer J., 1984, Badania wpływu zabudowy na klimat lokalny w Warszawie [The study of the influence of the structures on the local climate in Warsaw; in Polish], [in:] Materiały I Ogólnopolskiej Konferencji nt. "Klimat i Bioklimat Miast”. Wyd. UŁ, Łódź.

Stopa-Boryczka M., Kopacz-Lembowicz M., Kossowska-Cezak U., Mierzwiński B., Wawer J., 1986, Deformation of fields of meteorological elements under the influence of buildings, Miscellanea Geographica, vol. 2.

St op a-Boryczka M., 1988, Air temperature field deformation under the influence of builtup area, Miscellanea Geographica, vol. 3.

S to p a - B ory c zk a M., 1992, Z badań klimatu Warszawy Zakładu Klimatologii Uniwersytetu Warszawskiego [From the studies of the climate of Warsaw conducted by the Department of Climatology of the University of Warsaw; in Polish], Prace $i$ Studia Geograficzne, vol. 11 .

Stopa-Boryczka M., Kopacz-Lembowicz M., Błażek E., Kicińska B., Żmudzka E., 1994, The heat island in Warsaw and its effects, Miscellanea Geographica, vol. 5 .

Stopa-Boryczka M., Kopacz-Lembowicz M., Błażek E., Kicińska B., Żmudzk a E., 1995, Antropogeniczne zmiany temperatury powietrza w Warszawie - pozytywne i negatywne skutki [The anthropogenic changes in air temperature in Warsaw — the 
positive and negative effects; in Polish], II Ogólnopolska Konferencja "Klimat i Bioklimat Miast”, Wyd. Łódzkie, Łódź.

Stopa-Boryczka M., 1998, On thermal characteristic analysis of city climates, Miscellanea Geographica, vol. 8.

Wawer J., 1992, The impact of the weather conditions on the intensity of the urban heat island in Warsaw, Miscellanea Geographica, vol. 5.

Wawer J., 1996, The rate of heating and cooling of the air in town and outside of it, Miscellanea Geographica, vol. 7.

Waw e r J., 1998, Urban heat island in Warsaw, [in:] Urban and suburban landscapes as the subject of geographical research, Proc. of the Ist Polish-Russian Symposium, Warszawa, September 1995.

Waw e r J., 1998, Dependence of the urban heat island on the atmospheric circulation types, Miscellanea Geographica, vol. 8. 